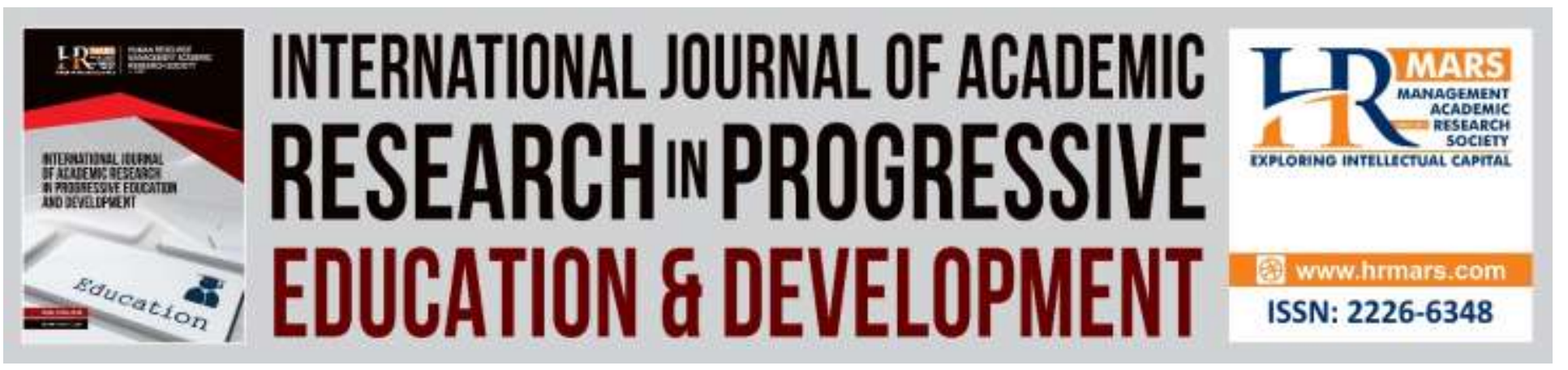

\title{
Exploring Disabled Students' Service Quality Dimensions: A Case of Malaysian Higher Education Institutions (HEls)
}

\author{
Wan Salmuni Wan Mustaffa, Rafiduraida Abdul Rahman, Hariyaty Ab \\ Wahid, Suriani Mohd Rhouse, Norlaile Salleh Hudin
}

To Link this Article: http://dx.doi.org/10.6007/IJARPED/v8-i2/5766

DOI: $10.6007 /$ IJARPED/v8-i2/5766

Received: 27 Feb 2019, Revised: 27 March 2019, Accepted: 18 April 2019

Published Online: 19 May 2019

In-Text Citation: (Mustaffa, Rahman, Wahid, Rhouse, \& Hudin, 2019)

To Cite this Article: Mustaffa, W. S. W., Rahman, R. A., Wahid, H. A., Rhouse, S. M., \& Hudin, N. S. (2019). Exploring Disabled Students' Service Quality Dimensions: A Case of Malaysian Higher Education Institutions (HEIs). International Journal of Academic Research in Progressive Education and Development, 8(2), 239248.

Copyright: (c) 2019 The Author(s)

Published by Human Resource Management Academic Research Society (www.hrmars.com)

This article is published under the Creative Commons Attribution (CC BY 4.0) license. Anyone may reproduce, distribute, translate and create derivative works of this article (for both commercial and non-commercial purposes), subject to full attribution to the original publication and authors. The full terms of this license may be seen at: http://creativecommons.org/licences/by/4.0/legalcode

Vol. 8(2) 2019, Pg. 239 - 248

Full Terms \& Conditions of access and use can be found at http://hrmars.com/index.php/pages/detail/publication-ethics 


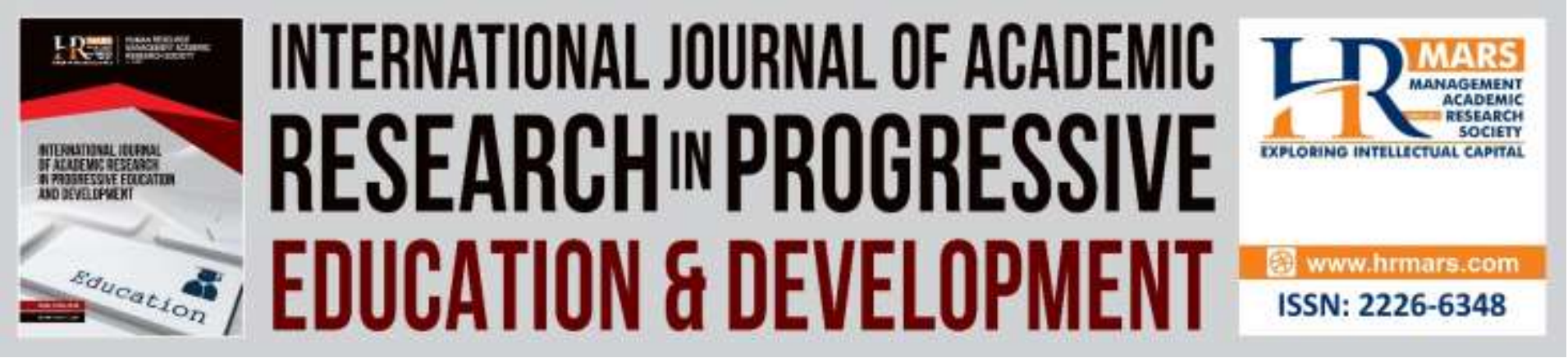

\title{
Exploring Disabled Students' Service Quality Dimensions: A Case of Malaysian Higher Education Institutions (HEls)
}

\author{
Wan Salmuni Wan Mustaffa, Rafiduraida Abdul Rahman, \\ Hariyaty Ab Wahid, Suriani Mohd Rhouse, Norlaile \\ Salleh Hudin \\ Department of Business Management and Entrepreneurship, Faculty of \\ Management and Economics, Universiti Pendidikan Sultan Idris, Malaysia.
}

\begin{abstract}
The aim of this research is to explore the crucial dimensions of service quality experienced by disabled students at Malaysian HEls. The Malaysian public universities were selected as a research context. This research involved disabled students registered at selected Malaysian public universities. Purposive sampling technique was utilized for selection of the respondents. Face-toface interview was conducted to gather the data. Thematic technique was performed to analyze the data. Result from the interview indicated that the disabled students were less satisfied with service experience offered by Malaysian public universities. The results also revealed that four dimensions need to give extra attention to improve the quality of disabled students' service experience at Malaysian HEls. The service dimensions include physical facilities, access to learning, communication, and empathy. This research will give a positive impact to the university's management in providing service quality according to the disabled students' needs.
\end{abstract}

Keywords: Service quality, service delivery, disabled students, higher education.

\section{Introduction}

The effectiveness of service delivery offered by Malaysian Higher Education Institutions (HEIs) will be more integrated and holistic if the interests of disabled students are also considered. Malaysia Education Blueprint 2015-2025 (Higher Education) outlines a crucial agenda related to quality and efficiency of service delivery to students, especially to students with disabilities. This is in line with Malaysia Plan of Action for People with Disabilities (PWDs) 2016-2022 which outlines the importance of upgrading the accessibility of the disabled people towards a quality and inclusive education at all educational level. This agenda has also been supported by the United Nation (UN) that acknowledged the importance of access to education among PWDs to assist them achieve an equality and recognition by the community (Hasnah et al., 2010). 
In 2017, data revealed by Ministry of Higher Education (MoHE) reported about 2444 disabled students had registered at Malaysian public universities. Yet, this number is too small as compared with the total student enrolment at higher education level, which contributes only $1.1 \%$ from total public universities students (MoHE Data Management Unit, 2017). In general, the universities have taken various initiatives to upgrade the quality of service delivery to the disabled students. However, the quality level of accessibility and disabled-friendly facilities of service delivery offered by Malaysian HEls is still unsatisfactory (Falina \& Safura, 2017). Consequently, these could possibly affect the opportunities and achievement of disabled students.

As reported in the previous research, the weaknesses aspects of service delivery offered to disabled students include poor physical facilities, inefficient of enrolment process and access to learning, and poor employees' awareness towards the needs of the disabled students (Reed, Kennett \& Emond, 2015; Falina et al., 2015; Hariza, 2012; Samsuri, 2012). Additionally, the measurement models to gauge the service quality specifically in the education industry such as HEdPERF, SERVQUAL and SERVPERF still fail to explore the service delivery experiences from the perspective of disabled students (Vaughan \& Woodruffe-Burton, 2011). Therefore, this research is conducted to explore the service quality dimensions experienced among disabled students, specifically at Malaysian public universities. Accordingly, the research outcomes will assist the HEls to increase the efficiency and quality service delivered to the students, especially to students with disabilities.

\section{Literature Review}

Overview of Service Quality Experience among Disabled Students in HEls

Research on access to education for disabled students has been conducted by researchers based on different views and approaches. Table 1 discusses the summary of researches on disabled students' perception towards service quality offered in HEls: 
INTERNATIONAL JOURNAL OF ACADEMIC RESEARCH IN PROGRESSIVE EDUCATION AND DEVELOPMENT

Vol. 8, No. 2, 2019, E-ISSN: 2226-6348 C 2019 HRMARS

Table 1 Researched on disabled students' perception towards service quality in HEls

\begin{tabular}{|c|c|}
\hline Researcher & Finding \\
\hline $\begin{array}{l}\text { Brodwin et al. (2002) } \\
\text { Hall \& Tinklin (1998) }\end{array}$ & $\begin{array}{l}\text { There are } 4 \text { obstacles of learning faced by the disabled } \\
\text { students in HEls: }\end{array}$ \\
\hline $\begin{array}{l}\text { McCarthy \& Campbell } \\
\text { (1993) }\end{array}$ & $\begin{array}{ll}\text { i. } & \text { Physical surrounding } \\
\text { ii. } & \text { Enrolment process } \\
\text { iii. } & \text { Information accessibility during study } \\
\text { iv. } & \text { Low awareness among academic and non- } \\
& \text { academic staffs }\end{array}$ \\
\hline Konur (2000) & $\begin{array}{l}\text { Discrimination towards the disabled students at every } \\
\text { level of studies including: } \\
\begin{array}{l}\text { i. Intake } \\
\text { ii. Enrollment } \\
\text { iii. Service channel } \\
\text { iv. Accommodation and graduation }\end{array}\end{array}$ \\
\hline $\begin{array}{l}\text { Brostrand (2006) } \\
\text { Longoria (2006) }\end{array}$ & $\begin{array}{l}\text { Myth and negative stereotype about disabled students } \\
\text { produce prejudice attitude in context of social, } \\
\text { education and vocational. }\end{array}$ \\
\hline $\begin{array}{l}\text { Abdul Munir et al. (2015) } \\
\text { Redpath (2013) } \\
\text { Holloway (2001) }\end{array}$ & $\begin{array}{l}\text { Stress on physical surrounding was the main obstacle to } \\
\text { disabled students at HEls such as access to campus, class, } \\
\text { library and support services. }\end{array}$ \\
\hline Hazlin \& Safura (2017) & $\begin{array}{l}\text { Weakness in the quality of facility for disabled students } \\
\text { is the main issue of disabled students' access to } \\
\text { education. }\end{array}$ \\
\hline
\end{tabular}

In conclusion, the service quality offered by HEls to disabled students are still poor and require continuous improvement. The most critical aspects that need to be improved by HEls is the physical facilities, enrolment process and staffs awareness towards the needs of disabled students.

\section{Service Quality Theory and Measurement Model}

Expectation Disconfirmation Paradigm (EDP) is a theory used to assess service quality within various service contexts (Anderson, 1973: Oliver, 1980; Olshavsky \& Miller, 1972). EDP theory defined service quality as the gap between customers' expectation of service and their perception towards service experience (Parasuraman et al., 1985, 1988, 1991). According to Buttle (1996), service quality refers to the capability of an organization to deliver high standard of services to fulfill the customers' expectations and requirements.

Based on EDP theory, SERVQUAL (service quality) model was developed and widely used to measure quality attributes across various service industries (Parasuraman et al., 1985, 1988, 1991). SERVQUAL consists of 22 indicators representing five dimensions of service quality, namely reliability, responsiveness, assurance, empathy and tangibles. Several researches had discussed the problems of SERVQUAL model including the ambiguity in its conceptualization, unclear theoretical 
justification of the customer' expectations, and the ambiguity in defining the relationship between service quality and customer satisfaction (Cronin \& Taylor, 1994; Sultan \& Wong, 2010; Teas, 1993). In order to overcome these issues, the SERVPERF model is developed to measure the service quality from the customers' perception only (Cronin \& Taylor, 1996). The literature has supported the validity of SERVPERF model due to its ability to produce better as compared to SERVQUAL expectation-perception analysis (Bayraktaroglu \& Atrek, 2010; Seth, Deshmukh \& Vrat, 2005)

HEdPERF (higher education performance) is a scale developed to measure service quality in higher education sector (Abdullah, 2005, 2006). The scale emphasized on quality delivery activities in higher education, includes academic and non-academic aspects from students' point of view. According to HEdPERF scale, service quality is conceptualized as assessment of total higher education services based on students' experience. HEdPERF instrument has been empirically tested for unidimensionality, reliability and validity using both exploratory and confirmatory factor analyses (CFA) (Abdullah, 2005). Although, SERVQUAL, HEdPERF and SERVPERF have been used in measuring service quality in HEls, these models still fail to measure service experience from disabled students' standpoint (Vaughan \& Woodruffe-Burton, 2011). In conclusion, there is a need to explore extensively the needs of disabled students towards the service quality offered by HEls.

\section{Methodology}

Population, sample and sampling technique

This research involved disabled students registered at Malaysian public universities. According to data revealed by MoHE (2017), a total of 2,444 disabled students had registered at Malaysian public universities (Data Management Unit, MOHE, 2017). In this research, five disabled students from the selected Malaysian public universities were involved in face-to-face interview. The purposive sampling technique was utilized to select the respondents for the interview process.

\section{Instrumentation}

A set of questions were developed based on the disabled students' experiences towards service quality offered by Malaysian public universities. The questions covered the education services aspects including the process, learning environment and facilities.

\section{Data Analysis}

In this research, the qualitative approach was applied as research design. The main reason of selecting this approach is to explore in depth the service quality aspects needed by the disabled students while studying at HEls. The qualitative data gathered were analyzed using the thematic technique.

\section{Data Analysis Result}

The face-to-face interview was conducted to extensively explore the disabled students' experiences towards service quality at Malaysian public universities. The disabled students involved in the research were given the code, ROKU1 (visual impairment), ROKU2 (physical disability), ROKU3 (deaf), ROKU4 (physical disability) and ROKU5 (speech impairment) to protect their identity. The results indicated that disabled students were less satisfied with the services 
offered by Malaysian public universities. The interviews' results had categorized the needs of disabled students into four main themes/dimensions, namely physical facilities, access to learning, communication and empathy.

i. Physical facilities dimension refers to the ability of the university in providing the disabled-friendly infrastructures. The followings are the interviews' results with the selected disabled students:

...... "ramp facility special for blind students and other facilities such as lift, wheelchair and toilet for disabled person are very much needed to help me move around. Even more important is having the tactical guiding block for the blinds".... (ROKU1)

"disabled-friendly infrastructure is very important especially the wheelchair ramp for wheelchair-bound user like myself" (ROKU2)

..........." overall, I feel the design of most building in public universities is still less disabledfriendly. This causes difficulties for disabled students to access route such as the usage of unsuitable door, floor finishing, textured path and incomplete ramp" (ROKU3)

"facility is not disabled-friendly especially the information counter is too high for me. I am a Little People, so it is very difficult for me to communicate with the staff at the counter..." (ROKU4)

............ "I still not satisfied with the available facilities...for example, the elevator is always not functioning causing us the disabled students unable to go to the level that we want to go.... Consequently, matters that need to be resolved on that day had to be postponed"... (ROKU5)

ii. Access to Learning dimension is defined as the extent to which the quality of teaching and learning delivered by the lecturers is able to meet the expectations of disabled students. The followings are the interviews' results with the selected disabled students:

"access to disabled-friendly learning equipment such as Braille and talkback feature in laptop and smartphone are not available, causing difficulties for disabled students to obtain accurate information"....(ROKU1)

..... "access to the academic sources is also difficult for the disabled students. I like to go to the library but the book racks are too high for me to reach the books that I want" (ROKU2)

"It's hard for me to hear clearly to lectures because there are lecture halls which does not have microphone for the lecturer to use" (ROKU3)

"The narrow space in the lecture hall and the crowded chairs and tables makes it hard for me on a wheelchair to enter the lecture hall" (ROKU4)

.I think reference materials and books are not enough for the disabled students" (ROKU5)

iii. Communication measures the extent to which the employees at university give a positive feedback when serving the services to the disabled students. The followings are the interviews' results with the selected disabled students: 
INTERNATIONAL JOURNAL OF ACADEMIC RESEARCH IN PROGRESSIVE EDUCATION AND

DEVELOPMENT

Vol. 8, No. 2, 2019, E-ISSN: 2226-6348 @ 2019 HRMARS

..... "there are staff who raised their voice when I am asking them questions.... don't feel comfortable".....(ROKU1)

..... "lecturers give less attention to me, maybe they are less exposed to disabled students"......(ROKU2)

...... "staff at the counter speaks too quick when dealing with us as if they do not understand our weaknesses"......(ROKU4)

......"I'm always excluded by lecturer during class activities, lecturer is more focused on able-bodied friends"......(ROKU5)

iv. Empathy refers to the service process and education environment that are sensitive to the needs of disabled students. The followings are the interviews' results with the selected disabled students:

"sometimes university staff gives slower response when I ask question...I have to wait long for the response"....(ROKU1)

"lecturers give us less attention"... (ROKU2)

"I feel the university staff still have less knowledge on disabled students' needs"......(ROKU3)

"I like studying at this university....it is just that the staffs are not sensitive with the existence of us the disabled students".....(ROKU4)

......... "the staff working here are all good people....however the service are quite slow, I have to wait a bit long".....(ROKU5)

\section{Discussion and Conclusion}

This research revealed that the disabled students were still less satisfied with service quality offered by the Malaysian public universities. The results of the interviews highlighted the service quality experienced by disabled students at Malaysian public universities were categorized into four main dimensions, namely physical facilities, access to learning, communication and empathy. Physical facilities refers to the ability of the university in providing the disabled-friendly infrastructures such as safe building design, disabled-friendly learning equipment and safe accessibility to the location in the university. The access to learning dimension measures the extent to which the quality of teaching and learning delivered by the lecturers is able to meet the expectations of disabled students, such as lecturers are aware of the needs of disabled students and involve them in learning activities. The communication dimension measures the extent to which the employees at university give a positive feedback when serving the services to the disabled students. Whereas, the dimension of empathy refers to the service process and education environment that are sensitive to the needs of disabled students, for instance the services offered are fair to those with disabilities.

This research can positively impact the university management to be more aware in providing quality service to disabled students according to their needs. In addition, this research can also increase the awareness and acceptance of disabled students among the campus community. The 
dimensions of the service quality including physical facilities, access to learning, communication and empathy are hoped to assist the university and the Ministry of Higher Education to construct strategies for better service delivery systems for disabled students.

\section{Limitation of Study}

This research also has its own limitations that can provide opportunities for future researchers to conduct further research. The exploration of dimensions of service quality experience among disabled students in this research was using the face-to-face interviews. Nevertheless, the types of disabilities involved were limited as the research only focused on students with physical, visual and auditory disabilities. In order to improve the reliability of the dimensions studied, future research can further expand the study population which encompasses various types of disabilities. This research used the qualitative technique in exploring the service quality experienced by the disabled students. However, the dimensions of the service quality developed can be validate using the quantitative technique such as Exploratory Factor Analysis and Confirmatory Factor Analysis.

\section{Acknowledgement}

The authors would like to extend their gratitude to Research Management Centre (RMIC), Universiti Pendidikan Sultan Idris, Perak, Malaysia for the University Research Grant (Code 20170260-107-01) that helped fund the research.

\section{Corresponding Author}

Email: wan.salmuni@fpe.upsi.edu.my

\section{References}

Abdullah, F. (2005). HEdPERF versus SERVPERF: The quest for ideal measuring instrument of service quality in higher education sector. Quality Assurance in Education, 13(4), 305-328.

Abdullah, F. (2006). The development of HEdPERF: a new measuring instrument of service quality for the higher education sector. International Journal of Consumer Studies, 30(6), 569-581.

Anderson, E. (1973). Consumer Dissatisfaction: The effect of disconfirmed expectancy on perceived product performance. Journal of Marketing Research, 10(1), 38-44.

Abdul Munir, I., Mazdi, M., Mohd Noor, D. \& Abdul Hadi, B. (2015). Penyediaan kemudahan orang kurang upaya (OKU) di masjid-masjid: Kajian kes di masjid-masjid daerah Batang Padang. Al-Hikmah. 7(1) 2015: 62-78

Bayraktaroglu, G., \& Atrek, B. (2010). Testing the superiority and dimensionality of SERVQUAL vs SERVPERF in higher education. Quality Management Journal, 17(1), 47-59.

Buttle, F. (1996). SERVQUAL: review, critique, research agenda. European Journal of Marketing, 30(1), 8-32.

Brostrand, H. L. (2006). Tilting at windmills: Changing attitudes towards people with disabilities. Journal of Rehabilitation. 72 (1): 4-9.

Brodwin, M. G., Orange, L. M. (2002). Attitude towards disability. Dalam J. D. Andrew \& C.W. Faubion (Eds.), Rehabilitation Services: An Introduction For The Human Services Professional: 145-173. Osage Beach, MO: Aspen Professional Services. 
INTERNATIONAL JOURNAL OF ACADEMIC RESEARCH IN PROGRESSIVE EDUCATION AND

DEVELOPMENT

Vol. 8, No. 2, 2019, E-ISSN: 2226-6348 @ 2019 HRMARS

Cronin, J Joseph, \& Taylor, S. A. (1994). SERVPERF Versus SERVQUAL : Reconciling performance-

based and measurement of service quality. Journal of Marketing, 58, 125-131.

Data Management Unit, Ministry of Higher education. (2017). Data for Public HEI for Disabled Students' Enrolment 2017. Malaysia.

Falina, H. R. \& Safura, A. S. (2017). Halangan fasiliti pelajar orang kurang upaya (OKU) di Institusi pengajian tinggi Di Lembah Klang. International Journal for Studies on Children, Women, Elderly And Disabled. 2 (June), 94-99.

Falina, H. R., Wan Amizah, W. M. \& Haizan, M. (2015). Realiti dan Kesamarataan Hak Orang Kelainan Upaya (OKU) di Malaysia. International Conferences on Media and Communication (MENTION 2015).

Hasnah, T., Tajul Arifin, M., Mohd Hanafi, M. Y., Mohd Mokhtar, T. \& Nur Hazwani, H. (2010). Pengetahuan dan sikap rakan sebaya terhadap pelajar kurang upaya di sebuah IPTA di Malaysia. Asean Journal of Teaching and Learning in Higher Education. 2 (2010), 21-32.

Holloway, S. (2001). The experience of higher education from the perspective of disabled students. Disability \& Society, 16, 597-615.

Hall, J. \& Tinklin, T. (1998). Students First: The Experiences of Disabled Students in Higher Education. Edinburgh: Scottish Council for Research in Education.

Konur, O. (2000). Creating enforceable civil rights for disabled students in higher education: an institutional theory perspective. Disability \& Society, 15(7), 1041-1063

Longoria, L., Marini I. (2006). Perceptions of children's attitudes towards peers with a severe physical disability. Journal of Rehabilitation 72 (3): 19-25.

McCarthy, M. \& Campbell, N. J. (1993). Serving disabled students: Faculty needs and attitudes. NASPA Journal, 30(2): 120-125.

Ministry of Women, Family and Community Development (2016). Disabled Action Plan, 2016-2022. Malaysia.

Ministry Of Higher Education (2016). Malaysia Education Blueprint 2015-2025 (Higher education). Malaysia.

Hariza, N. H. (2012) Aspirasi kerjaya dalam kalangan pelajar bermasalah pendengaran di politeknik. Tesis tidak diterbitkan.Universiti Tun Hussein Onn, Melaka, Malaysia.

Olshavsky, R. W., \& Miller, J. A. (1972). Consumer expectations, product performance and perceived product quality. Journal of Marketing, 9(Febuary), 19-21.

Parasuraman, A., Zeithaml, V. A., \& Berry, L. L. (1985). A conceptual model of service quality and its implications for future research. Journal of Marketing, 49(Fall 1985), 41-50.

Parasuraman, A., Zeithaml, V. A., Berry, L. L. (1988). SERVQUAL: A multiple-item scale for measuring consumer perceptions of service quality. Journal of Retailing, 64(1), 12-40.

Parasuraman, A., Zeithaml, V. A., Berry, L. L. (1991). Refinement and reassessment of the SERVQUAL scale. Journal of Retailing, 4(Winter 1991), 420-450.

Reed, M. J., Kennett, D. J., \& Emond, M. (2015). The influence of reasons for attending university on university experience: A comparison between students with and without disabilities. Active Learning in Higher Education, 16, 225-236.

Redpath, J., Kearney, P., Nicholl, P., Mulvenna, M., Wallace, J., \& Martin, S. (2013). A qualitative study of the lived experiences of disabled post-transition students in higher education institutions in Northern Ireland. Studies in Higher Education, 38, 1334-1350. 
Samsuri, N. A. (2012). Penyediaan fasiliti OKU di Sekolah Menengah Pendidikan Khas Vokasional Indahpura. Masters thesis, Universiti Tun Hussein Onn Malaysia.

Sultan, P., \& Wong, H. Y. (2010). Service quality in higher education - a review and research agenda. International Journal of Quality and Service Sciences, 2(2), 259-272.

Mustaffa, W. S. W., Rahman, R. A., Wahid, H. A., Rhouse, S. M., \& Hudin, N. S. (2019). Exploring Disabled Students' Service Quality Dimensions: A Case of Malaysian Higher Education Institutions (HEIs). International Journal of Academic Research in Progressive Education and Development, 8(2), 239-248.

Vaughan, E. \& Woodruffe-Burton, H. (2011). The disabled student experience: does the SERVQUAL scale measure up? Journal of Quality Assurance in Education. 19(1), 28-49 